FINAL REPORT TO DOE ELSI PROGRAM

Project ID: ER62990-1015861-0006131

\title{
INVESTIGATION OF THE ETHICAL CONCEPTS THAT INFORM THE LAWS LIMITING GENETIC SCREENING IN EMPLOYMENT DECISIONS: PRIVACY, HUMAN DIGNITY, EQUALITY, AUTONOMY, EFFICIENCY
}

PI: Dr. Lynn Pasquerella; Co-PI: Dr. Lawrence E. Rothstein; Institution: Univ. of Rhode Island

\section{$\underline{\text { Introduction }}$}

Genetic research has already begun to identify each gene and determine its function. The hope is that unlocking the human genome will enable researchers and clinicians not only to predict whether certain individuals will develop various conditions, but to advance technological responses to some of our most common and devastating genetically linked diseases, such as diabetes, heart disease, and cancer. The ability to both predict and treat diseases using genetic technology raises important questions regarding the ethical, social, and legal implications of the Human Genome Project. Of particular concern to many individuals is how these advances in technology might be used by employers to discriminate against asymptomatic workers whose genetic tests reveal information regarding future disease, disability, premature death, and the likelihood of passing on genetic conditions to their children. There is certainly strong economic incentive, especially for small, self-insured businesses, to hire and retain workers who are not only free from medical problems, but are also absent an identifiable risk of developing or creating offspring with future costly medical conditions. Escalating expenses related to employer provided health care and the need to provide reasonable accommodations in the workplace consonant with the Americans with Disabilities Act could thus prompt employers to either terminate or never hire those deemed too risky in terms of potential health problems.

State legislation has been the main locus of activity and the focus of our research because federal law has dealt only tentatively and often in a contradictory manner with the employment issues raised by recent genetics research. Under the federal Americans with Disabilities Act of 1990 1, which prohibits discrimination against disabled persons and may require reasonable accommodation for a disability, an individual is considered to be "disabled" if the individual either (1) has a physical or mental impairment which substantially limits one or more of that person's major life activities, (2) has a record of such an impairment, or (3) is regarded by the employer as having such an impairment.

In March 1995 the Equal Employment Opportunity Commission (EEOC), the federal agency having the responsibility to enforce Title I of the $\mathrm{ADA}$ and to issue regulations for its implementation, updated its Compliance Manual with respect to the third category listed above, individuals who are "regarded as having such an impairment." Specifically, the Compliance Manual, the purpose of which is to give guidance to EEOC investigators stated the following:

This part of the definition of "disability" applies to individuals who are subjected to discrimination on the basis of genetic information relating to illness, disease, or other disorders. Covered entities that discriminate against individuals on the basis of such genetic information are regarding the individuals as

$$
\begin{aligned}
& \text { DOE Pritent Cleasaree. Grantol } \\
& \text { fay Alm Las Mark Dvorscak }
\end{aligned}
$$




\section{DISCLAIMER}

This report was prepared as an account of work sponsored by an agency of the United States Government. Neither the United States Government nor any agency Thereof, nor any of their employees, makes any warranty, express or implied, or assumes any legal liability or responsibility for the accuracy, completeness, or usefulness of any information, apparatus, product, or process disclosed, or represents that its use would not infringe privately owned rights. Reference herein to any specific commercial product, process, or service by trade name, trademark, manufacturer, or otherwise does not necessarily constitute or imply its endorsement, recommendation, or favoring by the United States Government or any agency thereof. The views and opinions of authors expressed herein do not necessarily state or reflect those of the United States Government or any agency thereof. 


\section{DISCLAIMER}

Portions of this document may be illegible in electronic image products. Images are produced from the best available original document. 
having impairments that substantially limit a major life activity. Those individuals, therefore, are covered by the third part of the definition of "disability." 2

This interpretation by the EEOC, while significant, has not been approved by the federal courts.3

The $7^{\text {th }}$ Circuit Court of Appeals decision in EEOC v. Rockwell Int'l Corp. 4 concerning carpal tunnel syndrome susceptibility, indicates that the courts are not sympathetic to the EEOC's policy on genetic discrimination. The ADA could not easily apply to a gene sequence that would indicate hypersusceptibility to an environmental danger. In Norman-Bloodsaw v. Lawrence Berkeley Laboratory, 5 the Ninth Circuit held that the ADA does not preclude testing for genetic conditions as part of a pre-employment physical.

The U.S. Supreme Court's decision in Bragdon v. Abbott, 6 deeming apparently asymptomatic HIV infection a disability, may offer some hope of application to genetic conditions. In Bragdon the Court concluded that HIV infection in which the individual is not exhibiting any visible symptoms of illness is a "physical impairment" that substantially limits the major life activity of reproduction. It found that asymptomatic HIV is a physical impairment from the moment of infection due to "the immediacy with which the virus begins to damage the infected person's blood cells and the severity of the disease." 7 Bragdon was not an employment case, but one dealing with the refusal of dental services. While the possession of a gene that will at some point present as a serious disease and that may be passed on to offspring certainly affects reproductive decisions, some of the Court's more recent decisions raise doubts about its willingness to apply this more broadly to asymptomatic genetic conditions and to employment matters.

The Supreme Court's recent decisions in Sutton v. United Air Lines, Inc. Toyota Motors Mfg., Ky., Inc. v. Williams, Murphy v. United Parcel Serv., Inc. and Chevron v. Echazabal 8 suggest that it would be unsympathetic In Sutton and Toyota, the Court held that to be substantially limited in the major life activity of working, one must be precluded from more than one type of job and be unable to do a broad range of jobs, as well as to be without a reasonable means of correction of the putative disability. In Murphy the Court found that the plaintiff's employer did not regard him as substantially limited in the major life activity of working in a broad class of jobs, but rather regarded him as unqualified to work only in the particular job of a mechanic who was required to drive a commercial motor vehicle. 9 Most importantly, in Echazabal the court held that an employer, under the ADA and EEOC regulations, could consider harm to the employee himself, regardless of the employee's willingness to accept the risk, as "job-related and consistent with business necessity" grounds for refusing the employee work under conditions to which the employee was hypersusceptible.

In 1996, Congress enacted the Health Insurance Portability and Accountability Act (HIPAA).10 This law applies to employer-based health insurance coverage and allows employees to maintain insurance coverage if they change or leave their jobs." Under this law, a group health insurance plan cannot use "genetic information" to establish rules for eligibility or continued eligibility, and cannot treat genetic information as a "preexisting condition in the absence of the diagnosis of the condition related to such information." Again, while significant, this law provides very limited protection against misuse of genetic information. 
HIPAA does not regulate the discriminatory conduct of the $60 \%$ of all employers who are self-insured or the HMOs that ERISA exempts from state insurance laws. The Act does not address genetic privacy concerns such as the dissemination of genetic information. It fails either to prohibit or to regulate genetic testing requirements by insurers. It does not prohibit the use of genetic information in risk classification and insurance underwriting. Finally, HIPAA fails to prohibit employers from genetically discriminating against people seeking health insurance. 11

ERISA also works to impede the effort of state laws that might prevent an employer from eliminating coverage for an employee's potential condition. Sec. 1144 (a) of the Employee Retirement Income Security Act of 197412 preempts state laws that attempt to regulate employee benefit plans. Thus, under ERISA all self-funded employee benefit plans are exempted from state insurance regulations. These plans cover 125 million employees and family members. Federal courts have consistently held that self-insured employers may eliminate aspects of coverage based on consideration of costs. The Fifth Circuit, for example, upheld an employer's right to alter the entire self-funded employee benefit package in response to one beneficiary's claims in McGann v. H\& H Music Co. 13 In Curtiss-Wright Corp. v. Schoonejongen 14, the Supreme Court approved an employer's revision of a health plan removing coverage from certain retirees based on a reservation clause in the benefit plan--which clause stated merely that the company reserved the right to modify or amend any or all provisions of its plan.

State legislators have thus been facing the issue of the collection and use of genetic information in employment matters in an environment where the technological implications, the human resource policies and the effects of federal law are uncertain.15

\section{Object of the Research}

The broad question addressed in our research is: What is the influence of ethical concepts on legislative outcomes? The research focuses on the important ethical concerns that surround the use of genetic information in employment matters and the importance of those ethical concerns in American state legislatures. By analyzing the content of hearings, interviews, news articles and advocacy documents involved in the state legislative process, we seek to answer the question: How might the dominance of a particular ethical concept informing the discussion of a bill influence the legislative outcome?

Consistently in the legislative discussion of the use of genetic information, ethical concepts such as privacy, human dignity, equality, autonomy, and efficiency are used. It is evident that the emphasis on one concept rather than another paints a very different picture of the use of genetic information. The range of legislation presently in effect in 31 states and being considered in others is broad. The legislation may prohibit discrimination in hiring, firing and/or terms and conditions of employment; may prohibit employers from requesting, requiring or even obtaining genetic information or genetic tests; may define the proscribed genetic information as including genetic test results, information about genetic testing, family history and/or information about any inherited characteristics or susceptibilities; and may or may not prescribe specific penalties or 
remedies for breach. The legislation may also include or be linked to provisions that require informed consent for genetic testing or for the acquisition or release of genetic information. Can these differences be attributed to differences in the emphasis given the ethical concepts by those dealing with the legislation, primarily legislators, experts, advocates and lobbyists?

The ethical concepts drawn from the existing literature, observation of the legislative process and documents on genetic testing in the workplace were subsumed under five broad categories: autonomy, (human) dignity, efficiency, equality and privacy. These concepts play integral, but differing, roles in legislative discussions about the use of genetic testing in the workplace.

For instance, reliance on a concept such as privacy portrays the employer's access to genetic information as an intrusion into an intimate protected zone of the employee's life over which an employee has rights akin to those of property. Similarly, the concept of human dignity emphasizes the power and primacy of human identity, social relationships, participatory rights and humane treatment. The employee is not just a statistically regarded factor of production determined by her or his genetic makeup and her life should not be completely transparent to the employer. It is the obtaining of the information itself that violates notions of privacy and dignity; although dignity encompasses notions of humane treatment as well. These concepts might well lead to legislation that is primarily concerned with restricting the employer's access to the information.

On the other hand, emphasizing equality focuses on the unfair use of the information to discriminate against an employee based on factors over which she or he has no control, which are fraught with uncertainty and which may have only tenuous ties to job performance. The resulting legislation is likely to take the form of adding the prohibition of discrimination on the basis of genetic information to existing civil rights laws.

Autonomy enables individuals to exercise their decision making capacities, enhance their ability to reason, promote self-development, recognize moral principles and act in accordance with them. The concept implies that at work, the employee reserves some freedom concerning, and control over, the means of performing the tasks assigned and is personally responsible for facing, ignoring or overcoming genetic risks. A concern for autonomy might result in ADA- type laws that require the employer to respect and accommodate the employee's decisions about her health.

There are significant sub-terms related to the broad categories of autonomy and privacy that must be considered in relation to this philosophical analysis as well. For instance, allowing employers access to genetic information in the workplace without violating a worker's autonomy requires informed consent on the part of the employee. Indeed, the legal and moral requirements of informed consent follow from the principle of respect for autonomy. Without adequate information and the absence of coercion, autonomous decision making cannot take place. The requirement of confidentiality of medical information is related to privacy. The employee has the right to determine who should have access to private information concerning his or her medical conditions and the right to rely on promises made regarding the distribution of this information. 
Providing confidential information to others without an individual's consent unacceptably limits a patient's self-determination. The only possible exceptions occur when a breach of confidentiality is necessary to prevent harm to others.

If we are justified in restricting autonomy to prevent harm to others, are we entitled to consider economic harm along with physical harm? This is where arguments from business necessity, under the category of efficiency, come into play. Presumably, the employer has a duty to protect the business by controlling costs which may mandate regulating the behavior of employees. In circumstances where a genetic predisposition creates risks that might result from exposure to toxins in the workplace, employers could argue that these hypersusceptible employees impose an unacceptable financial burden both to the company and to other employees. For other employees, the threat comes from the loss of job security when working for a business with growing financial exigencies and from the risk of increased costs under group health plans.

A working statement of our hypothesis is that legislation, at least that dealing with a novel technology in an environment of great uncertainty and purporting to bring under new forms of control important and intimate aspects of human existence, will be influenced in its passage and in its form by the ethical concepts familiar to, and used in discussion by, key decision makers.

\section{Methodology}

\section{Data Collection}

The data consists of bills proposed, statutes passed, testimony and materials submitted to legislators and legislative committees considering the bills, open-ended surveys and interviews of those participating in the deliberations over the bills. Data was collected initially collected from every state. Bills and statutes were identified through the National Council of State Legislatures data bases and Lexis-Nexis. We contacted bill sponsors and committees considering the bills as well as legislative reference services or Secretary of State offices in the states. Through these contacts, we are able to obtain access to committee documents, hearing transcripts and opportunities to conduct mail, email and telephone interviews with many of the significant participants. Studies of Congress have indicated that the committee hearing is the most important locus and source of technical information for legislators. 16 What is true for Congresspersons, who have a substantial staff, is even more true for state legislators with very little staff.

The states initially settled on for further data collection, interviews and analysis were Rhode Island, Massachusetts, Maine, Hawaii, Vermont, Nebraska, Oregon, Maryland, Louisiana, Michigan and Connecticut. These states were chosen for several reasons. They represented a cross-section both geographically and of different types of legislation. They also had extensive hearings and reports providing the best access to data. However, as the research progressed, changes in the legislative picture developed. By 2002 every one of these states had genetic discrimination in employment legislation in effect and all but Maine and Hawaii covered both use and collection of genetic information. For that reason we now find it necessary to add the states of Kentucky, Florida and Illinois, which have no legislation restricting the use of genetic testing or information in employment decisions and North Carolina, which has use only genetic 
discrimination legislation.

\section{Treating the Ethical Concepts}

The collected data was then transcribed or scanned for digitizing. Data was analyzed through the use of "Concordance", a textual analysis program, which counts the uses of words, organizes the counts of words which signify the concepts sought and shows the context of each counted word allowing for correction and verification by the co-investigators. 17 The count for each key concept included the concept word itself and those words we coded for the concept. The coded words were derived partly from a linguistic analysis of the five key concepts and partly from analyzing selected pre-test documents from the legislative process. 18 The concept word list is attached as an appendix to this report.

After analyzing the content of all of the documents and interviews from a state through the Concordance program and verifying the word counts with independent reviews by the other researchers, a percentage was calculated by dividing the use of concept words indicating each of our key concepts by the use of the total of concept words for that state. This percentage, which we called the "\%MENTION", is a rough measure of the relative importance of each ethical concept in that state's legislative process. The hypothesis that the normalized number of mentions of terms referring to the ethical concepts of privacy, dignity, autonomy, equality and efficiency correlated with the type of legislation proposed and/or passed, required that we also analyze and categorize the bills or laws so that we could use the \%MENTION a term as the independent variable and the law category as the dependent variable.

\section{Categorizing the Legislation}

We began to develop our bill/law categories by analyzing the NCSL table of state genetic non-discrimination statutes and bills. In August 2001, 28 (31 as of August 2002) states had laws on the books that dealt with genetic testing and employment. All of these prohibited discrimination based on the results of genetic tests. Six of the states merely added genetic discrimination to their anti-discrimination laws. One of these six specified penalties for genetic discrimination separately from other forms of discrimination. There were also differences in the scope of genetic information covered. Nine of the states included not only the results of the test but any information about a genetic test, particularly whether the employee had been advised to take, took or refused to take such a test. Nine $(12$ in 8/02) of the states broadened the basis for prohibiting discrimination to family history indicating genetic conditions. These provisions focus on what may not be done with genetic information that the employer may obtain.

Aside from the above provisions which seemed to be clearly motivated by fears of discrimination, twenty ( 24 in 8/02) states specifically prohibited employers from requiring genetic information. These provisions, then, deal with what genetic information the employer may obtain about the employee. Seventeen $(8 / 02-18)$ states prohibited employers from requesting genetic information. Thirteen $(8 / 02-16)$ states specifically barred employers from administering genetic tests and nine states barred employers from obtaining genetic information.19 No existing legislation, but some of the bills introduced, would have required employers to make reasonable 
accommodation for those who on their own behest submitted information about genetic conditions. These latter provisions seem less linked to non-discrimination or equality concerns than they are to notions of privacy, human dignity and autonomy, which emphasize a worker's right to determine what constitutes acceptable risk without paternalistic intervention by the employer.

The analysis of the legislation and the bills considered indicates at this preliminary stage two clear divisions with gradations in each regarding scope. The first division protects the employee from the employer's usage of genetic information to affect hiring, firing, promotion or other terms and conditions of employment. Gradations within this division have to do with how narrow or expansive is the definition of genetic information and how serious are the sanctions prescribed. The second division aims at protecting the employee from the employer obtaining genetic information. Here again gradations within the division are based on what kind of genetic information is covered and the nature of sanctions provided against the employer. 20

The gradations within each category regarding the scope of genetic information covered and the serousness of sanctions, we hypothesize, will be strongly, but negatively, correlated with the occurrence of the ethical concept labeled "efficiency". This concept covers values related to the cost and availability of genetic information needed for the most effective and economical performance of business, research and clinical functions.21 It is the issue which we have seen most often raised by business, insurance, pharmaceutical, research and clinical interests through their lobbyists and used to argue for more limited individual protections.

\section{Passage or Failure to Pass}

The statutes or bills were then coded and analyzed in the following manner.22 A distinction was made between those bills which were not passed and enacted statutes. By the end of the data collection period, however, every state for which we had collected significant amounts of data had passed a relevant statute. We are presently adding the other states mentioned above. The analysis of passage or failure to pass will require a twofold cross-tabulation. First, a $5 \times 2$ table with each of the five main value concepts reading down and columns for pass or fail. In the first column of cells will be recorded the number of states with an enacted statute whose highest $\%$ MENTION or LEAD VALUE was the row value. The second column would be the number of states with the corresponding LEAD VALUE and no enacted statute. The second mode of analysis would be a $3 X 5$ table with the rows labeled ONE LAW ENACTED, SIX LAWS ENACTED and ELEVEN LAWS ENACTED and a column for the \%MENTION of each of the five concepts at which the specified level of enactment existed. These tables should give us a rough idea of whether the emphasis on a particular ethical value in legislative testimony and evidence may influence passage of a law limiting the use of genetic testing or information in employment matters.

\section{Type of Legislation}

Next the legislation was categorized by type: legislation prohibiting the use of genetic tests or information for discriminating in employment decisions $(\mathrm{U})$; legislation prohibiting genetic 
testing or the collection of genetic information (C); or legislation combining these prohibitions (UC). Here again, by the end of the data collection period originally forecast, we found that only two states, Maine and Hawaii, had U type legislation. All of the rest with enacted laws had UC type legislation. We found that we would need at least one more state with $U$ type legislation to provide an adequate cross-section and have added North Carolina. No state in our original designation had $\mathrm{C}$ type legislation alone nor was there any state that could be added with such legislation. The analysis of this data will first require cross-tabulation by means of a $5 \times 2$ table, the rows being designated LEAD VALUE with a row for each of the five ethical concepts, and a column each for the number of states with that LEAD VALUE having $U$ type legislation or UC type legislation. The second cross-tab will make use of a $3 \times 5$ table with the rows designated $U$, UC and NONE and the columns designated by the names of each of the five ethical concepts. In each cell will be the average of the \%MENTION values for that ethical concept over all of the states having the designated type of or no legislation. These tables and cross-tabs should give us an idea of the relation, if any, between the values and the type of legislation passed.

\section{Strength of Legislation}

In calculating the strength of the legislation, we gave one point for the inclusion of each of the following ten provisions: a) prohibited discrimination based on the results of a genetic test; b) prohibited discrimination based on genetic information (defined more widely than, but including, the results of a genetic test or whether a person had taken a genetic test); c) prohibition of discrimination covered all terms and conditions of employment; d) prohibition of requiring a genetic test; e) prohibition of requesting a genetic test; f) prohibition of requiring genetic information (defined as noted above); $\mathrm{g}$ ) prohibition of requesting genetic information; $h$ ) requirement of reasonable accommodation for genetic susceptibility to workplace hazards; i) provided for enforcement by civil or criminal penalty; and j) provided for specific agency or official to enforce prohibitions. This provided for a maximum strength of ten points. See the table below.23 


\begin{tabular}{|l|l|}
\hline STATE & $\begin{array}{l}\text { STRENGTH OF } \\
\text { LEGISLATION } \\
(0-10)\end{array}$ \\
\hline CT & 8 \\
\hline FL & 0 \\
\hline HI & 3 \\
\hline IL & 0 \\
\hline KY & 0 \\
\hline LA & 7 \\
\hline MA & 8 \\
\hline MD & 8 \\
\hline ME & 8 \\
\hline MI & 5 \\
\hline NC & 2 \\
\hline NE & 6 \\
\hline OR & 5 \\
\hline RI & 7 \\
\hline VT & 5 \\
\hline
\end{tabular}


A $5 X 1$ table with the five rows indicated by LEAD VALUE naming each of the five ethical concepts and one column designated AVG. STRENGTH with an average of the STRENGTH values for each state having the LEAD VALUE for that row. Five graphs will be used to analyze the effect of \%MENTION of each ethical concept. The X-axis will contain \%MENTION of the particular concept and the Y-axis STRENGTH. The data point coordinates will be the figures for each state. This table and graph will give us a notion of whether the five ethical concepts or any one of them influence the strength of the legislation passed.

\section{Findings to Date}

Because we have had to add states to our analysis to get an adequate cross-section and we have only recently received key data from many of the states, we have not yet been able to carry out the systematic statistical analyses mentioned above. We estimate that the completion of additional data collection and full statistical analysis will take another 4-6 months. Despite the ending of the grant period, we will continue the work using our own resources until we have finished the project as it was proposed..

At this stage a qualitative look at the data we have collected leads us to the following very preliminary conclusions. Our findings, although supported by the data we have collected, are still more impressionistic than systematic. Furthermore, some of the findings go beyond what our methodology is designed to test for. Our contact with legislators, experts and advocates is suggesting answers to other large questions concerning genetic information and its handling. For example, is genetic information different from other medical information? 24 We would have to say that most legislators we have contacted, i.e. those with a special interest in, or responsibility for decision making on, the subject matter of genetics, believe it is different. The same is true for advocates and lobbyists who are concerned with those about whom genetic information would be gleaned. Minnesota is to date the only state that has folded the protection of genetic information into its strong general medical records confidentiality provisions. 25 Most often those who argue that genetic information is no different from other medical information are attempting to head off safeguards for the collection or use of genetic information. $\mathbf{2 6}$

We find four elements to the belief that genetic information is different from other medical information: 1) There are still great uncertainties regarding whether, when and to what extent a gene will be expressed as a medical condition; 2) Given the uncertainties there is too great a possibility that someone will be unfairly stigmatized or have a limited future because of employers' misperceptions or overly cautious attitudes; 3) The resolving of the uncertainties, however, raises the fear that genetic test results will furnish a "future diary" into the most intimate aspects of a person's life opening it up both to unwanted scrutiny and to a deterministic and paternalistic denial of autonomy and choice on the part of the individual; 4) Finally, there are great concerns for the ripple effect of genetic information that is revelatory not only about the individual from whom the genetic sample is taken but all of that person's blood relations.

Another finding is that the legislative discussion on early attempts (early 1990s) to pass legislation restricting genetic testing in employment matters were characterized by little resistance. Generally the legislation was moved by pro-restriction interest groups such as the ACLU, labor 
unions or organizations representing sufferers from genetic conditions. Legislators with a personal interest in the issue either took the lead or were recruited by these groups to introduce and shepherd the legislation. Employers and their organizations did not turn out to oppose it and bills were sent to labor or technology committees for consideration, passed with little opposition and at times little discussion. The discussion did focus on moral issues such as nondiscrimination, fairness, privacy and autonomy.

While employment oriented legislation has still not generated strong employer opposition, more recent bills have been coupled with restrictions on research, insurers and HMOs, bringing out those communities' representatives in more serious opposition. These bills have often been sent to corporations or insurance committees for deliberation. The pro-restriction interests have continued to set the tone of discussion so that even the anti-restriction interests must make ethical arguments. The anti-restriction arguments tend to focus on what we have called "efficiency", but have also raised a fairness argument that the maximum availability of information reduces costs to patients, makes insurance coverage accessible for more people and maximizes the development of new and better treatments.

The legislative processes have been characterized, although recently less so, by what political scientists have called "deliberative" (i.e. on the merits) discussions rather than political bargaining (i.e. log rolling, compromise and interest accommodation). This may be characteristic of legislation dealing at an early stage with a novel technology, in an environment of uncertainty, purporting to bring under new forms of control important and intimate aspects of human existence. Employers are only gradually becoming aware of the potential for the new technology and are only gradually overcoming their personal abhorrence of its intrusiveness. Legislators are therefore freer to exercise their independent judgments in this situation. Insurance companies and medical providers are more knowledgeable and more directly involved in exploiting the new technologies. Legislators' freedom of deliberative action is diminishing and interest accommodation is becoming more important in recent committee processes dealing with the use of genetic information in health insurance and research. 27

Yet, employment oriented legislation has been heavily influenced by the emphasis on genetic discrimination in the documents, interviews and hearing transcripts which we have received. It is no surprise that this emphasis has led to legislation that focuses on the use of genetic tests or data to affect employment opportunities and that no employment oriented legislation deals with the collection issue alone. Even where the legislation is of the UC variety (as most of the pieces of legislation we have analyzed are), we find that the prohibition of the collection of genetic information or of the requiring or requesting genetic tests is motivated by fears of their use to discriminate against employees. The strength of the legislation seems to be more influenced by the depth and extent of consideration given to it than by the influence of any of our studied ethical concepts. 


\section{Dissemination and Related Products of the Research}

"Genetics, Ethics and the Law: Basic Concepts and Case Studies," (with Lynn Pasquerella) presentation to Issues in Biotechnology classes at Connecticut College and the University of Rhode Island, 2001-present.

"The Ethical, Legal and Social Implications of the Human Genome Project for Newborn Screening," presentation to the Public Health \& Genetics Symposium, Providence, RI April 29, 2002.

"Some Ethical Considerations for IRBs on Genetic Issues," (with Lynn Pasquerella and Harold Bibb) professional development seminar for researchers and IRB members, Kingston, RI, December 11, 2001.

"Genethics: Genetics, Ethics, Law and Employment," ( with Lynn Pasquerella) presentation to American Society for Microbiology Micro -By-The-Sea Conference, Groton, CT, October 24, 2001.

"Privacy in the Workplace: Electronic \& Genetic Monitoring," presentation to Labor Arbitration Conference, Providence, RI, October 12, 2001.

"Genetics, Ethics, and Democracy: Ethical Concepts in Lawmaking Concerning Genetic Technology," paper presented to the American Society for Law, Medicine \& Ethics conference on Health, Law and Human Rights: Exploring the Connections, Philadelphia, PA, October 1, 2001 and at the Nature \& Technology Conference, Aberdeen, UK, July 10, 2001 (with Lynn Pasquerella).

"Exploration of Confidentiality in the New World of Genetics," panelist, Cranston, RI, November $6,2000$.

As a result of this research project, we have developed a substantial number of contacts in state, federal and private genetics decision making bodies. Dr. Rothstein is a member of the Rhode Island Dept. of Health Genetics Advisory Committee, the Social and Ethical Concerns Committee of the Northeast Region Genetics Group and the conference faculty for the American Society of Law, Medicine \& Ethics' Health, Law and Human Rights Conference. Dr. Pasquerella serves as well on the latter two and is head of URI's IRB and the Ethics Committee of her local hospital.

Another offshoot of the research sponsored by DOE is our just completed, semester long Fall 2002 colloquium on Genetics, Ethics and Public Policy in the New Millennium. We brought in speakers each week to discuss the implications of genetic technologies including genetic testing, forensic genetics, cloning, agricultural genetics, xenotransplantation, genetic therapies and stem cell research. The speakers included George Annas, Phillip Reilly, Barry Scheck, Christopher Reeve, Dan Brock, Dorothy Wertz, Troy Duster and Oliver Sacks. Along with this program, we taught an honors course for 70 students. 


\section{NOTES}

1. 42 U.S.C. $12101-12213$ (1994).

2. EEOC Compliance Manual, $\S 902.8$ (1995).

3. Wendy Lovejoy, "Ending the Genetic Discrimination Barrier: Regaining Confidence in Preconception, Prenatal, and Neonatal Genetic Testing," Southern California Law Review 74 (2001 ): 873-911; Barry Guryan, "Genetic Discrimination in Employment," paper delivered at the Whitehead Policy Symposium: Genes and Society, Cambridge, MA, May 10, 2000.

4. 243 F. 3d 1012 ( $7^{\text {th }}$ Cir. 2000).

5. 135 F.3d $1260\left(9^{\text {th }}\right.$ Cir. 1998$)$.

6. 524 U.S. 624 (1998).

7. 524 U.S. at 637.

8. 119 S. Ct. 2139 (1999), 122 S. Ct. 681 (2002), 119 S. Ct. 2133 (1999) and 122 S. Ct. 2045 (2002)

9. Paul Steven Miller, "Is There a Pink Slip in my Genes? Genetic Discrimination in the Workplace," Journal of Health Care Law \& Policy 3 (2000): 225-65.

10. 29 U.S.C. 1181 et seq. (2002)

11. Lovejoy, supra n. 33: at 903-905.

12. 29 U.S.C. 1144 (a) (2002).

13. 946 F.2d 401 ( $5^{\text {th }}$ Cir. 1991).

14. 115 S. Ct. 1223 (1995).

15. See e.g. William D. Murry, James C. Wimbush \& Dan R. Dalton, "Genetic Screening in the Workplace: Legislative and Ethical Implications," Journal of Business Ethics 29 (February 2001): 365-378.

16. Joseph M. Bessette, The Mild Voice of Reason (Chicago: Univ. of Chgo. Press, 1994); Hugh Heclo, "Issue Networks and the Executive Establishment," in A. King, ed., The New American Political System (Washington: American Enterprise Inst., 1978): 87-124; Allen Schick, "Informed Legislation: Policy Research Versus Ordinary Knowledge," in W. H. Robinson \& C. H. Wellborn, eds., Knowledge, Power and the Congress (Washington: CQ Press, 1991): 99-119; Barbara Hinckley, "Policy Content, Committee Membership and Behavior," American Journal of 
Political Science 19 (1975): 543-557; Carol H. Weiss, "Comment” (on Schick, 1991), in W. H. Robinson \& C. H. Wellborn, eds., Knowledge, Power and the Congress (Washington: CQ Press, 1991): 120-5; John W. Kingdon, Congressmen's Voting Decisions (Ann Arbor: Univ. of Mich. Press, 1992).

17. Rob Watt, Concordance ver. 2.0 (2000).

18. Randy Hodson, Analyzing Documentary Accounts (Thousand Oaks: Sage, 1999); Robert P. Weber, Basic Content Analysis (Thousand Oaks: Sage, 1990); Herbert J. Rubin \& Irene S. Rubin, Qualitative Interviewing: The Art of Hearing Data (Thousand Oaks: Sage, 1995); Stephen Ackroyd \& John Hughes, Data Collection in Context (London: Longman, 1992).

19. National Conference of State Legislatures, State Genetic Non-Discrimination in Employment Laws (visited May 6, 2001 and November 25, 2002)

$<$ http://www.ncsl.org/programs/health/genetics/ndiscrim.htm $>$.

20. Mark A. Rothstein, Betsy D. Gelb \& Steven G. Craig, "Protecting Genetic Privacy by Permitting Employer Access Only to Job-Related Employee Medical Information: Analysis of a Unique Minnesota Law," American Journal of Law \& Medicine 24 (1998): 399-416.

21. Charity Scott, "Is Too Much Privacy Bad for Your Health? An Introduction to the Law, Ethics, and HIPAA Rule on Medical Privacy," Georgia State University Law Review 17 (Winter 2000): 481-529.

22. W. Phillips Shively, The Craft of Political Research (Upper Saddle River: Prentice-Hall, 2002): $117-132$

23. Conn. Gen. Stat. $\S 46 a-60$ (2001) (CT); 2002 Hi. Act 217 (HI); La. R.S. 23:368 (2002) (LA); MGL ch. 151B, $\S 1$ et seq. (2002) (MA); Md. Ann. Code art. 49B, § 15 et seq. (2002) (MD); 5 M.R.S. § 19301 et seq. (2001) (ME); MCLS § 37.1201 et seq. (2002) (MI); N.C. Gen. Stat. § 95-28.1A (2001) (NC); R.R.S. Neb. § 48-236 (2002) (NE); ORS § 659A.300 et seq. (2001) (OR); 2002 R.I. Pub. Laws 49 (RI); 18 V.S.A. § 9331 et seq. (2002) (VT).

24. Jon Beckwith \& Joseph S. Alper, "Reconsidering Genetic Anti-discrimination Legislation," Journal of Law, Medicine \& Ethics 26 (1998): 205-210; George J. Annas, Some Choice: Law, Medicine, and the Market (Oxford Univ. Press, 1998): Ch. 9.

25. Rothstein, Gelb \& Craig, supra n. 20.

26. Thomas H. Murray, "Genetic Exceptionalism and 'Future Diaries': Is Genetic Information Different from other Information?" in M.A. Rothstein, ed., Genetic Secrets: Protecting Privacy and Confidentiality in the Genetic Era (New Haven: Yale Univ. Press, 1997): 60-73.

27. Bessette, supra n.16. 


\section{CONCEPT LIST}

autonomy

autonomous

choice

choices

choose

choosing

chose

conform

conformed

conforming

conformity

conforms

consent

consent

consented

consenting

consents

decide

decided

decides

deciding

decision

decision-making

decisionmaking

decisions

diversity

doctor-patient

doctor/patient

empower

empowered

empowering

empowerment

empowers

expose

exposed

exposes

exposing

exposure

exposures

free

freedom

knew

know knowing

knowledge

knows

physician-patient

physician/patient

power

powerful

powers

risk

risked

risking

risks

self

self-determination

self-determine

self-determines

self-determined

self-determining

susceptibilities

susceptibility

susceptible

writing

written

dignity

anonymity

anonymous

destine

destined

destines

destinies

destining

destiny

determinism

determinist

deterministic

future

human

humane

humanity

identities

identity

impersonal

impersonality individuality

meaning

personality

predict

predicted

predicting

prediction

predictions

predicts

predispose

predisposed

predisposes

predisposing

predisposition

predispositions

probabilities

probability

probable

relationship

relationships

soul

souls

spirit

spirits

spiritual

spirituality

stigma

stigmas

stigmatization

stigmatizations

stigmatize

stigmatized

stigmatizes

stigmatizing

efficiency

actuarial

aggregate

aggregate

aggregated

aggregates

aggregating

aggregation

allocate 


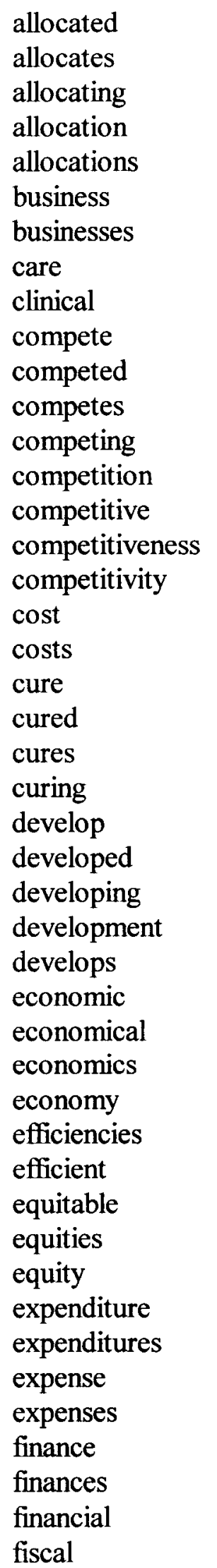

$\begin{array}{ll}\text { government } & \text { accommodated } \\ \text { governments } & \text { accommodates } \\ \text { liabilities } & \text { accommodating } \\ \text { liability } & \text { accommodation } \\ \text { liable } & \text { accommodations } \\ \text { manage } & \text { anti-discrimination } \\ \text { managed } & \text { anti-discriminatory } \\ \text { management } & \text { antidiscrimination } \\ \text { manages } & \text { antidiscriminatory } \\ \text { managing } & \text { bias } \\ \text { market } & \text { biased } \\ \text { marketed } & \text { biases } \\ \text { marketing } & \text { biasing } \\ \text { markets } & \text { capabilities } \\ \text { necessary } & \text { capability } \\ \text { necessitate } & \text { capable } \\ \text { necessitates } & \text { characteristic } \\ \text { necessitating } & \text { characteristics } \\ \text { necessities } & \text { denial } \\ \text { necessity } & \text { denials } \\ \text { price } & \text { denied } \\ \text { priced } & \text { denies } \\ \text { prices } & \text { deny } \\ \text { pricing } & \text { denying } \\ \text { property } & \text { disabilities } \\ \text { quality } & \text { disability } \\ \text { regulate } & \text { disabled } \\ \text { regulated } & \text { discriminate } \\ \text { regulates } & \text { discriminated } \\ \text { regulating } & \text { fiscriminates } \\ \text { regulation } & \text { handirness } \\ \text { regulations } & \text { discriminating } \\ \text { research } & \text { discrimination } \\ \text { resource } & \text { discriminations } \\ \text { resources } & \text { discriminatory } \\ \text { statistical } & \text { equal } \\ \text { statistics } & \text { exclude } \\ \text { treat } & \text { excluded } \\ \text { treated } & \text { excludes } \\ \text { treating } & \text { excluding } \\ \text { treatment } & \text { exclusion } \\ \text { treatments } & \text { exclusions } \\ \text { treats } & \text { fair } \\ \text { accommodate } & \text { fandicapped } \\ & \end{array}$




\begin{tabular}{|c|c|c|}
\hline $\begin{array}{l}\text { handicaps } \\
\text { inequalities } \\
\text { inequality } \\
\text { job } \\
\text { jobs } \\
\text { non-discrimination } \\
\text { non-discriminatory } \\
\text { nondiscrimination } \\
\text { nondiscriminatory } \\
\text { perform } \\
\text { performance } \\
\text { performed } \\
\text { performing } \\
\text { performs } \\
\text { qualification } \\
\text { qualified } \\
\text { qualifies } \\
\text { qualify } \\
\text { qualifying } \\
\text { stereotype } \\
\text { stereotyped } \\
\text { stereotypes } \\
\text { stereotypical } \\
\text { stereotyping } \\
\text { task } \\
\text { tasks } \\
\text { terminate } \\
\text { terminated } \\
\text { terminates } \\
\text { terminating } \\
\text { termination } \\
\text { terminations } \\
\text { terms } \\
\text { unequal } \\
\text { unfair } \\
\text { unfairness } \\
\text { woman } \\
\text { women } \\
\text { work-related } \\
\text { brother } \\
\text { brothers } \\
\text { child } \\
\text { children } \\
\text { confidential } \\
\text { a }\end{array}$ & $\begin{array}{l}\text { confidentiality } \\
\text { cousin } \\
\text { cousins } \\
\text { disclose } \\
\text { disclosed } \\
\text { discloses } \\
\text { disclosing } \\
\text { disclosure } \\
\text { disclosures } \\
\text { families } \\
\text { family } \\
\text { father } \\
\text { fathers } \\
\text { identifiable } \\
\text { intimacy } \\
\text { intimate } \\
\text { intrude } \\
\text { intruded } \\
\text { intrudes } \\
\text { intruding } \\
\text { intrusion } \\
\text { intrusions } \\
\text { invade } \\
\text { invaded } \\
\text { invades } \\
\text { invading } \\
\text { invasion } \\
\text { invasions } \\
\text { legacies } \\
\text { legacy } \\
\text { liberties } \\
\text { liberty } \\
\text { limit } \\
\text { limitation } \\
\text { limitations } \\
\text { limited } \\
\text { limiting } \\
\text { limits } \\
\text { mother } \\
\text { mothers } \\
\text { own } \\
\text { ownership } \\
\text { personal } \\
\text { personalities } \\
\text { personality }\end{array}$ & $\begin{array}{l}\text { private } \\
\text { protect } \\
\text { protected } \\
\text { protecting } \\
\text { protection } \\
\text { protections } \\
\text { protects } \\
\text { release } \\
\text { released } \\
\text { releases } \\
\text { releasing } \\
\text { restrict } \\
\text { restricted } \\
\text { restricting } \\
\text { restriction } \\
\text { restrictions } \\
\text { restricts } \\
\text { right } \\
\text { rights } \\
\text { sibling } \\
\text { siblings } \\
\text { sister } \\
\text { sisters }\end{array}$ \\
\hline
\end{tabular}

